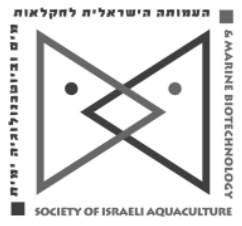

The IJA appears exclusively as a peerreviewed on-line Open Access journal at http://www.siamb.org.il Sale of IJA papers is strictly forbidden.

\title{
Effect of Three Diets on Growth and Survival Rates of African Catfish Heterobranchus bidorsalis Larvae
}

\section{Yao Laurent Alla ${ }^{1}$, Ble Melecony Célestin ${ }^{1}$, Atse Boua Célestin ${ }^{1}$, Kone Tidiani $^{2}$}

${ }^{1}$ Centre de Recherches Océanologiques, BPV 18 Abidjan, Côte d'Ivoire

${ }^{2}$ Laboratoire d'Hydrobiologie, UFR Biosciences, Université de Cocody Abidjan, 22 BP 582 Abidjan 22, Côte d'Ivoire

(Received 23.2.10, Accepted 14.4.10)

Key words: Heterobranchus bidorsalis, growth, survival, Artemia salina, beef brain, formulated food

\begin{abstract}
Investigations are underway in the Centre de Recherches Océanologiques d'Abidjan (Côte d'Ivoire) to find whether the catfish (Heterobranchus bidorsalis) could be an interesting aquaculture species. Within this framework a 28-day aquarium culture feeding trial was conducted to investigate the effects of three diets (Artemia salina nauplii, beef brain enriched with vitamins, and a compound food) on the growth and survival rates in 2-day post hatch $\mathrm{H}$. bidorsalis. The feeding experiments started after the yolk sac of the larvae was absorbed (initial mean weight $=2.03 \pm 0.38 \mathrm{mg}$ ). Larvae fed Artemia nauplii had a higher growth rate (final mean weight $=708.60 \pm 411.61 \mathrm{mg}$ ] than those fed beef brain (381.81 $\pm 118.88 \mathrm{mg}$ ) or compound food $(102.72 \pm 48.09 \mathrm{mg})$. Conversely, the beef brain diet yielded a better survival rate

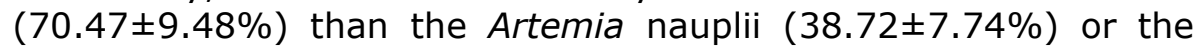
compound diet $(5.37 \pm 2.24 \%)$. Thus, beef brain can be used as a starter food for larval rearing of $\mathrm{H}$. bidorsalis.
\end{abstract}

* Corresponding author. E-mail: laurentalla@yahoo.fr 


\section{Introduction}

Catfishes are important commercial species throughout the world, especially in the intertropical zone of Africa (Teugels, 1994). Species such as Heterobranchus longifilis and Clarias gariepinus are widely cultured for their growth performance, resistance to intensive rearing conditions, and meat quality (Kerdchuen, 1992; Imorou Toko et al., 2008). However, in African catfish culture, supply of fingerlings for commercial production appears to be a major constraint.

Many investigations have shown that this weakness could be related to difficulties encountered during the early stages of culture. In addition to the effects of stocking density, weaning time and feed quality affect the success of larvae culture and mortality records show that cannibalism during the larval stage is a major constraint in fingerling production.

Brine shrimp (Artemia sp.) nauplii or decapsulated cysts are excellent starter feeds for freshwater and marine fish species (Legendre and Teugels, 1991; Dhert and Sorgeloos, 1994; Lavens and Sorgeloos, 1996; Olurin and Oluwo, 2010) but are very expensive for African fish culturists (Imorou Toko et al., 2008). Compound feeds based on yeast powder, beef liver, and zooplankton, which are less expensive and locally available, have been suggested as suitable alternatives (Kerdchuen, 1992; Kerdchuen and Legendre, 1994).

Some freshwater fish larvae can be reared exclusively on artificial diets from first feeding (Dabrowski et al., 1986; Appelbaum and Van Damme, 1988). A good alternative for catfish larvae is fertilization of ponds with organic fertilizers, including manure, that serve as algal nutrients and stimulate production of zooplankton that feed the growing larval population. This technique is often used to prepare new ponds for fry. Unfortunately, it does not seem to be suitable for intensive catfish culture, probably because of the high mortality (cannibalism) rates.

In the hatchery of Centre de Recherché Océanologiques d'Abidjan (CRO, Côte d'Ivoire), a diet made of beef brain enriched with vitamins is empirically used to feed catfish larvae for fry production. Beef brain was chosen because it is available, inexpensive, and easy to prepare. Likewise, its protein content is relatively high. This study was designed to evaluate the effects of this diet on growth and survival rates of Heterobranchus bidorsalis (Geoffroy SaintHilaire, 1809) larvae to see whether it could be an interesting candidate for tropical aquaculture. Comparisons are made with two other dietary treatments: Artemia salina nauplii and a compound feed.

\section{Materials and Methods}

Experimental fishes. Heterobranchus bidorsalis larvae were produced at the hatchery of the Centre de Recherches Océanologiques d'Abidjan using methods developed by Legendre (1986). They were counted and transferred to aquaria the day after hatching. The feed experiment began the next morning when the yolk sacs were almost completely absorbed.

Experimental diets. Three diets (Artemia salina nauplii, enriched beef brain, compound feed) were tested (Tables 1). Artemia cysts were incubated 
and hatched under optimal conditions (Slembrouck and Legendre, 1988; Kerdchuen and Legendre, 1994). After $24-32 \mathrm{~h}$ incubation at $30^{\circ} \mathrm{C}$ in artificial seawater, the nauplii were collected,

Table 1. Composition of beef brain and compound feeds.

\begin{tabular}{llr}
\hline & Component & \multicolumn{1}{c}{$\%$} \\
\hline Beef brain feed & Beef brain & 93.80 \\
& Yolk egg & 4.70 \\
& Biacalcium & 0.94 \\
& Cod-liver oil & 0.56 \\
& & \\
Compound feed & Wheat & 23.00 \\
& Fishmeal & 21.00 \\
& Soja & 21.00 \\
& Maize & 17.72 \\
& Cotton & 11.40 \\
& Copra & 5.70 \\
& Cod-liver oil & 0.10 \\
& Vitamins & 0.08 \\
\hline
\end{tabular}
separated from the cyst shells, washed, and used as feed for the catfish larvae. The beef brain feed was prepared by blending $1 \mathrm{~kg}$ beef brain in a mixer with $50 \mathrm{~g}$ chicken egg yolk, $10 \mathrm{~g}$ Biacalcium (iron, zinc, manganese, calcium, phosphorus, vitamins A, D3, E, B1, B2, C, and K3; Laboratoitres Biové, France), and $6 \mathrm{~g}$ cod-liver oil. After mixing, the brain diet was frozen at $-18^{\circ} \mathrm{C}$ until used. The compound dry feed was prepared from wheat, fishmeal, soyabean meal, cotton, and copra, and given as flour (Slembrouck and Legendre, 1988).

Three to five grams of each diet were used for chemical analysis (Table 2). Moisture was calculated as the difference between the fresh and the dry weights of two or three samples, weighed and dried in an oven at $105^{\circ} \mathrm{C}$ for $6 \mathrm{~h}$. Ash was determined as the difference between the fresh and dry weights of diet samples after 12-18 $\mathrm{h}$ in an oven at $600^{\circ} \mathrm{C}$. Protein and lipid contents were determined by the methods of Kjeldahl and Soxlet, respectively.

Table 2. Proximate analysis of experimental diets ( $\%$ of dry matter).

\begin{tabular}{lccc}
\hline & \multicolumn{3}{c}{ Diet } \\
\cline { 2 - 4 } & $\begin{array}{c}\text { Artemia } \\
\text { salina }\end{array}$ & $\begin{array}{c}\text { Beef } \\
\text { brain }\end{array}$ & $\begin{array}{c}\text { Compound } \\
\text { food }\end{array}$ \\
\hline Moisture & 67.58 & 74.29 & 7.64 \\
Ash & 6.78 & 10.50 & 9.09 \\
Lipid & 2.77 & 7.39 & 7.77 \\
Protein & 57.28 & 38.63 & 34.56 \\
\hline
\end{tabular}

Water quality. The experiment took place in 50-I aquaria in a tap-water recirculating system provided with mild aeration and ribbon-like perching substrates made of nylon netting. About $75 \%$ of the water in the system was replaced weekly to prevent accumulation of waste products. Water temperature and dissolved oxygen were measured daily using a YSI Model 58 oxygen meter (Yellow Springs Instruments). $\mathrm{pH}$ was determined daily using a $\mathrm{pH}$ meter (model WTW). These measurements were performed in each aquarium every morning between $8: 30$ and 9:00. The mean temperature was $27.2 \pm 0.2^{\circ} \mathrm{C}$, mean dissolved oxygen $5.8 \pm 0.4 \mathrm{mg} / \mathrm{l}$, and mean $\mathrm{pH} 7.2 \pm 0.1$.

Experimental procedures. Larvae $(2.03 \pm 0.38 \mathrm{mg}, 6.4 \pm 0.45 \mathrm{~mm})$ were randomly stocked into nine aquaria at a density of 10 larvae/l. The diets were tested in triplicate. The larvae were held in darkness and fed to excess four times per day at 9:00,12:00, 15:00, and 18:00. Aquaria were cleaned carefully every morning by siphoning off feces and uneaten food. The feeding rate was adjusted daily, based on the biomass in each aquarium. The experiment lasted 28 days. 
Data collection. Every three days, 30 larvae per aquarium (90 larvae per treatment) were randomly sampled for length and weight measurement. Total length was measured to the nearest $0.1 \mathrm{~mm}$ using a dial caliper. Individual body weight was taken using a Mettler balance with $0.1 \mathrm{mg}$ sensitivity. The fish were placed on tissue paper and transferred to a glass beaker containing water. The beaker was weighed before and after introduction of the larvae to determine the weight of the larvae. The larvae were returned to the aquarium immediately after weighing. The number of dead fish was recorded daily. Survival (\%) was determined at the end of the experiment by counting the remaining larvae in each aquarium. Coefficients of variation were determined as standard deviation $\times 100 /$ mean weight or mean total length; condition factor $(\%)$ as weight $\times 100 /$ length $^{3}$; mean daily weight gain $(\mathrm{g} / \mathrm{d})$ as $(\mathrm{Wf}-$ $\mathrm{Wi} / \mathrm{t}$ where Wi and $\mathrm{Wf}$ are the initial and final mean weights of the fish and $\mathrm{t}$ is the duration of the growth period in days; total biomass $(\mathrm{g})$ as weight of remaining larvae in each aquarium for each diet; and food conversion ratio as total amount of food consumed/Wf - Wi.

Statistical analysis. Data were expressed as means \pm SE. Length and weight data were log normalized $\log (x+1)$ before analysis. The effects of diet were tested with one-way analysis of variance (ANOVA), followed by Tukey's test. Differences were considered significant when $p<0.05$. Statistical analyses were performed using STATISTICA 7.1 software.

\section{Results}

Growth was better in larvae fed Artemia than in those fed beef brain or compound feed (Fig. 1, Table 3). Survival significantly differed between diets and was better in larvae fed beef brain (70.47 $\pm 9.48 \%)$ than in those fed $A$. salina $(38.72 \pm 7.76 \%)$ or compound food $(5.37 \pm 1.24 \%)$.
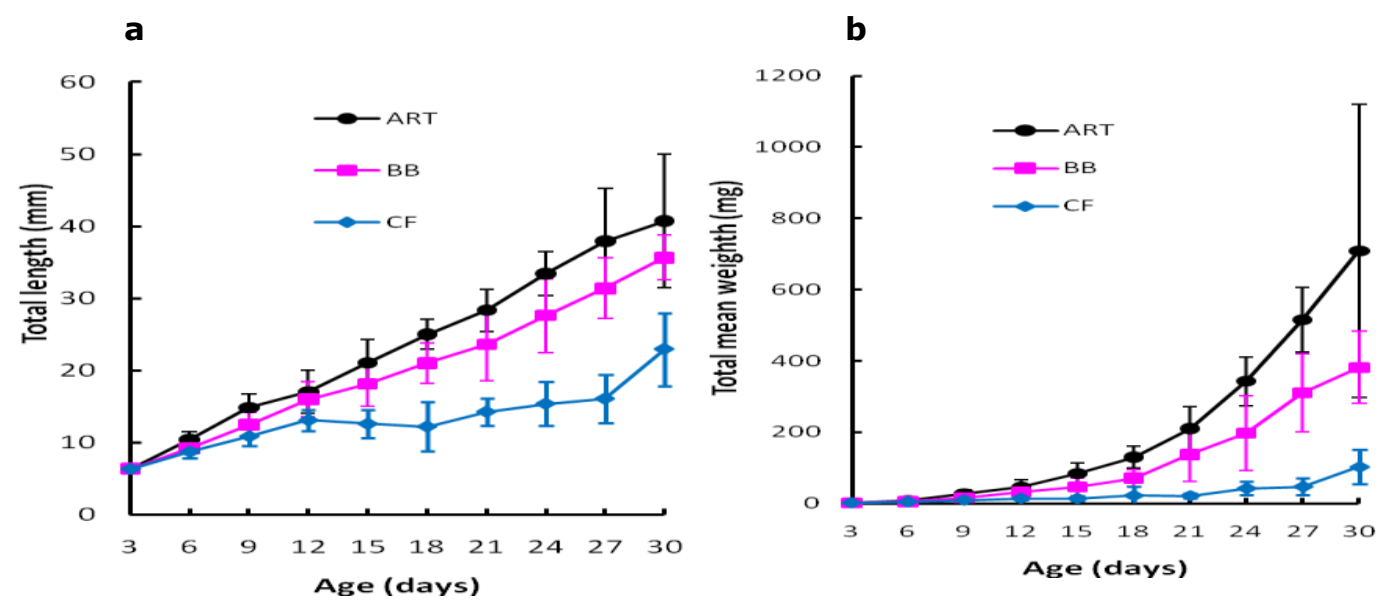

Fig. 1. Total mean length (a) and weight (b) of Heterobranchus bidorsalis larvae fed Artemia salina (ART), beef brain feed (BB), or compound feed (CF) for 28 days. Vertical bars represent standard deviations between triplicates. 
Table 3. Growth of Heterobranchus bidorsalis larvae $(2.03 \pm 0.38 \mathrm{mg}, 6.4 \pm 0.45 \mathrm{~mm})$ reared in aquaria and fed one of three diets for 28 days.

\begin{tabular}{lccc}
\hline & \multicolumn{3}{c}{ Diet } \\
\cline { 2 - 4 } & Artemia salina & Beef brain food & Compound food \\
\hline Final mean wt (mg) & $708.60 \pm 411.61^{\mathrm{a}}$ & $381.81 \pm 100.88^{\mathrm{b}}$ & $102.72 \pm 48.09^{\mathrm{c}}$ \\
Mean daily wt gain (mg/day) & $25.23 \pm 0.81^{\mathrm{a}}$ & $13.56 \pm 5.15^{\mathrm{b}}$ & $3.60 \pm 1.04^{\mathrm{c}}$ \\
Coefficient of variation of mean wt (\%) & $58.08 \pm 17.28^{\mathrm{a}}$ & $26.42 \pm 2.70^{\mathrm{b}}$ & $46.82 \pm 6.93^{\mathrm{c}}$ \\
Total biomass (g) & $137.18 \pm 45.08^{\mathrm{a}}$ & $134.53 \pm 43.38^{\mathrm{a}}$ & $2.75 \pm 0.69^{\mathrm{b}}$ \\
Final total mean length (mm) & $40.75 \pm 9.26^{\mathrm{a}}$ & $35.65 \pm 3.12^{\mathrm{b}}$ & $22.95 \pm 5.04^{\mathrm{c}}$ \\
Coefficient of variation of total length (\%) & $22.72 \pm 0.52^{\mathrm{a}}$ & $8.75 \pm 3.45^{\mathrm{b}}$ & $21.97 \pm 4.28^{\mathrm{a}}$ \\
Condition factor K & $0.82 \pm 0.10$ & $0.87 \pm 0.07$ & $0.82 \pm 0.23$ \\
Food conversion ratio & $3.36 \pm 0.97^{\mathrm{a}}$ & $9.29 \pm 1.88^{\mathrm{b}}$ & $18.78 \pm 6.82^{\mathrm{c}}$ \\
\hline
\end{tabular}

\section{Discussion}

Larvae fed Artemia salina grew better than those fed the beef brain or the compound diet. The mean final weight, daily weight gain, and total biomass of these larvae were higher than those obtained with other diets (Kerdchuen, 1992; Kerdchuen and Legendre, 1994; Legendre et al., 1994), probably because its protein content and amino acid composition were richer than in other diets.

Artemia salina is generally accepted as an initial feed for good growth and survival of C. gariepinus (Hogendoorn, 1980; Verreth et al., 1993; Adeyemo et al., 1994; Appelbaum and McGeer, 1998). The low food conversion ratio obtained with Artemia in the present study shows that this diet was well accepted by the larvae. This result can be explained by its very high nutritive value, due to its high protein level that can reach 62\% (Hamre et al., 2002). Moreover, decapsulated Artemia salina cysts are suitable as a starter feed for some fish larvae because they combine the advantages of live and dry diets (Vanhaecke et al., 1990; Garcia-Ortega et al., 2000; Olurin and Oluwo, 2010).

Survival was higher in the beef brain treatment than in the Artemia or compound diet treatments. The main reason was that larvae growth in this treatment was homogeneous, as shown by the low coefficients of variation for weight and length. Homogeneity of larval size greatly reduced cannibalism which, according to Baras et al. (1999), starts in vundu catfish four days after hatching and decreases when a mean weight of $30 \mathrm{~g}$ is reached.

The compound feed produced the lowest growth and survival because small fish are not acclimated to pelleted feed and have a less-developed digestive tract. Similar results were found in C. lazera (Hogendoorn, 1980), C. gariepinus (Verreth and Van Tongeren, 1989), H. longifilis (Kerdchuen, 1992; Kerdchuen and Legendre, 1994), wallago attu (Giri et al., 2002), and Clarias macrocephalus (Evangelista et al., 2005). These authors showed that low growth could be related to the development stage of the larval digestive system: larvae of this age cannot fully digest such food. These reasons can explain why the compound diet was not well assimilated, i.e., had a high food conversion ratio. Although many species are weaned only after complete 
development of their digestive system, red drum (Sciaenops ocellantus) and gilthead seabream (Sparus auratus) have successfully been weaned to microparticulate diets after only a few days on live foods (Holt, 2000).

Although very little is known about the nutritional requirements of $H$. bidorsalis larvae, beef brain proved to be suitable for rearing larvae. Survival was better with beef brain than with Artemia salina. The ingredients of the beef brain diet are locally available and relatively inexpensive compared to Artemia nauplii. Therefore, it can be recommended that beef brain be used as a substitute for Artemia nauplii during larvae rearing.

\section{Acknowledgements}

The authors thank the Director of the Centre de Recherche Océanologiques (CRO Côte d'Ivoire) and the staff of the Aquaculture Department for their contribution to this study.

\section{References}

Adeyemo A.A., Oladosu G.A. and A.O. Ayinla, 1994. The growth and survival of fry of African catfish species, Clarias gariepinus Burchell, Heterobranchus bidorsalis Geoffroy Saint-Hilaire and Heteroclarias reared on Moina dubia in comparison with other first feeds. Aquaculture, 119:41-45.

Appelbaum S. and J.C. McGeer, 1998. Effect of diet and light regime on growth and survival of African catfish (Clarias gariepinus) larvae and early juveniles. Aquacult. Nutr., 4:157-164.

Appelbaum S. and P. Van Damme, 1988. The feasibility of using exclusively artificial dry feed for the rearing of Israeli Clarias gariepinus (Burchell, 1822) larvae and fry. J. Appl. Ichthyol., 4:105-110.

Baras E., Tissier F., Philippart J.C. and C. Mélard, 1999. Sibling cannibalism among juvenile vundu under controlled conditions. II. Effect of body weight and environmental variables on periodicity and the intensity of type II cannibalism. J. Fish Biol., 54:106-118.

Dabrowski K., Takashima F., Strüssmann C. and T. Yamazaki, 1986. Rearing of coregonid larvae with live and artificial diets. Bull. Jpn. Soc. Sci. Fish., 52:23-30.

Dhert P. and P. Sorgeloos, 1994. Live feeds in aquaculture. pp. 209-219. In: K.P.P. Nambiar, T. Singh (eds.). Aquaculture Towards the 21st Century. Proc. INFOFISH-AQUATECH 94, Int. Conf. on Aquacult., INFOFISH, Colombo, Sri Lanka.

Evangelista A.D., Fortes N.R. and C.B. Santiago, 2005. Comparison of some live organisms and artificial diet as feed for Asian catfish Clarias macrocephalus (Günther) larvae. J. Appl. Ichthyol., 21:437-443.

Garcia-Ortega A., Verreth J., Van Hoornyyck A. and H. Segner, 2000. Heat treatment affects protein quality and protease activity in decapsulated cysts of Artemia when used as starter food for larvae of African catfish Clarias gariepinus (Burchell). Aquacult. Nutr., 6:25-31.

Giri S.S, Sahoo S.K., Sahu B.B., Sahu A.K, Mohanty S.N., Mukhopadhyay P.K. and S. Ayyappan, 2002. Larval survival and growth in 
wallago attu (Bloch and Schneider): effects of light, photoperiod and feeding regimes. Aquaculture, 213:151-161.

Hamre K., Opstad I., Espe M., Solbakken J., Hemre G.I. and K. Pittman, 2002. Nutrient composition and metamorphosis success of Atlantic halibut (Hippoglossus hippoglossus, L.) larvae fed natural zooplankton or Artemia. Aquacult. Nutr., 8:139-148.

Hogendoorn H., 1980. Controlled propagation of the African catfish Clarias lazera (C. \& V.). III. Feeding and growth of fry. Aquaculture, 21:233-241.

Holt G.J., 2000. Symposium on recent advances in larval fish nutrition. Aquacult. Nutr., 6:141.

Imorou Toko I., Fiogbé E.D. and P. Kestemont, 2008. Determination of appropriate age and stocking density of vundu larvae, Heterobranchus longifilis (Valenciennes 1840), at the weaning time. Aquacult. Res., 39:24-32.

Kerdchuen N., 1992. L'alimentation artificielle d'un silure africain, Heterobranchus longifilis (Teleostei: Clariidae). Incidence du mode d'alimentation et première estimation des besoins nutritionnels. ORSTOM Trav. Doc., 88:182.

Kerdchuen N. and M. Legendre, 1994. Larval rearing of an African catfish, Heterobranchus longifilis (Teleostei: Clariidae): a comparison between natural and artificial diet. Aquat. Living Resour., 7:247-253.

Lavens P. and P. Sorgeloos, 1996. Manuel on the Production and Use of Live Feed for Aquaculture. FAO Fish. Tech. Paper. $361 \mathrm{pp}$.

Legendre M., 1986. Seasonal changes in sexual maturity and fecundity and HCG-induced breeding of catfish Heterobranchus longifilis (Clariidae), reared in Ebrie lagoon (Côte d'Ivoire). Aquaculture, 55:201-213.

Legendre M. and G.G. Teugels, 1991. Développement et tolérance à la température des œufs de Heterobranchus longifilis, et comparaison des développements larvaires de $H$. longifilis et de Clarias gariepinus (Teleostei, Clariidae). Aquat. Living Resour., 4:227-240.

Legendre M., Kerdchuen N., Corraze G. and P. Bergot, 1994. Larval rearing of an African catfish Heterobranchus longifilis (Teleostei, Clariidae): effect of dietary lipids on growth, survival and fatty acid composition of fry. Aquat. Living Resour., 8:355-363.

Olurin K.B. and A.B. Oluwo, 2010. Growth and survival of African catfish (Clarias gariepinus) larvae fed decapsulated Artemia, live Daphnia, or commercial starter diet. Isr. J. Aquacult. - Bamidgeh, 62(1):50-55.

Slembrouck J. and M. Legendre, 1988. Aspects Techniques de la Reproduction Contrôlée de Heterobranchus longifilis. Cent. Rech. Océanogr., Abidjan. 19 pp.

Teugels G.G., 1994. Taxonomy, phylogeny and biogeography of siluriformes: an overview. p. 16. In: Atelier International sur les Bases Biologiques de I'aquaculture des Siluriformes. 24-27 May, Montpellier.

Vanhaecke P., De Vrieze L., Tackaert W. and P. Sorgeloos, 1990. The use of decapsulated cysts of the brine shrimp Artemia as direct food for carp Cyprinus carpio L. Iarvae. J. World Aquacult. Soc., 21:257-262. 
Verreth J. and M. Van Tongeren, 1989. Weaning time in Clarias gariepinus (Burchell) larvae. Aquaculture, 83:81-88.

Verreth J., Eding E.H., Rao G.R.M., Huskens F. and H. Segner, 1993. A review of feeding practices, growth and nutrition physiology in larvae of the catfishes Clarias gariepinus and Clarias batrachus. J. World Aquacult. Soc., 24:135-144. 